\title{
Resilience in In-Home Caregivers of Older Adults during the COVID-19 Pandemic*
}

\author{
Elizabeth Fajardo Ramosa - Martha Lucia Núñez Rodríguez • Angela Maria \\ Henao Castañoc
}

\begin{abstract}
Objective: This study aims to identify the resilience level in formal and informal in-home caregivers of older adults in Ibagué during the COVID-19 pandemic. Methods: Quantitative, descriptive, cross-sectional study with a convenience sample of 49 formal and informal in-home caregivers of older adults. We administered the Brief Resilient Coping Scale (BRSC), an instrument consisting of four items, to these caregivers. The questionnaire was self-completed and, in some cases, answered by telephone. The data were collected in April 2020. Results: 35 women and 14 men participated in this study. The formal (69.4\%) and informal caregivers, mostly family (30.6\%), were between 18 and 30 years old (65.30\%). Their resilience levels were high (16.3\%), moderate (61.3\%), and low (22.4\%). There was a significant association between caregiver type and resilience level ( $p \leq 0.05)$. Other studied covariates did not show a significant association. Conclusions: Due to stressful situations caused by care during social isolation and the risk of death of the elderly by COVID-19, strategies to improve resilience related to emotional, cognitive, and sociocultural interventions in the caregiver should be considered.
\end{abstract}

Keywords: Resilience; elderly; caregiver; COVID-19; formal caregiver; family

* Research article

a MSN. Nurse. Full professor, Universidad del Tolima. Ibagué, Colombia.

E-mail: efajardo@ut.edu.co

ORCID: https://orcid.org/0000-0002-3484-1620

b MEd. Cardiorespiratory Nursing Specialist. Nurse. Associate professor, Universidad del Tolima. Ibagué, Colombia.

E-mail: mnunez@ut.edu.co ORCID: https://orcid.org/0000-0002-2012-6554

c PhD in Nursing. MEd. Critical Care Nursing Specialits. Assistant professor, Nursing School, Universidad Nacional de Colombia. Bogotá, Colombia.

E-mail: angmhenaocas@unal.edu.co

ORCID: https://orcid.org/0000-0003-4203-0016 
Recibido: 15/05/2020

Acceptado: 30/11/2020

Disponible en línea: 23/04/2021

Cómo citar: Fajardo E, Núñez ML, Henao AM. Resilience in In-Home Caregivers of Older Adults during the COVID-19 Pandemic. Rev. latinoam. bioet [Internet]. 2021Apr.23 [cited 2021Apr.23];20(2): 91-101. Available from: https://doi.org/10.18359/rlbi.4813

\section{Resiliencia en cuidadores en casa de adultos mayores durante la pandemia del COVID-19}

Resumen: Objetivo: este estudio tiene como objetivo identificar el nivel de resiliencia en cuidadores formales e informales de adultos mayores en el hogar en Ibagué durante la pandemia del COVID-19. Métodos: estudio cuantitativo, descriptivo y transversal con una muestra de conveniencia de 49 cuidadores formales e informales de adultos mayores en el hogar. Aplicamos la Escala Breve de Afrontamiento Resiliente (BRSC), un instrumento que consta de cuatro puntos, para estos cuidadores. Ellos mismos completaron el cuestionario y, en algunos casos, lo respondieron por teléfono. Los datos se recopilaron en abril de 2020. Resultados: 35 mujeres y catorce hombres participaron en este estudio. Los cuidadores formales $(69,4 \%$ ) y los cuidadores informales, en su mayoría familiares (30,6\%), tenían entre 18 y 30 años (65,30\%). Sus niveles de resiliencia fueron altos (16,3\%), moderados $(61,3 \%)$ y bajos $(22,4 \%)$. Hubo una asociación significativa entre el tipo de cuidador y el nivel de resiliencia $(p \leq 0,05)$. Otras covariables estudiadas no mostraron una asociación significativa. Conclusiones: debido a las situaciones de estrés causadas por la atención durante el aislamiento social y el riesgo de muerte de los adultos mayores por COVID-19, se deben considerar estrategias para mejorar la resiliencia mediante intervenciones emocionales, cognitivas y socioculturales en el cuidador.

Keywords: resiliencia; adulto mayor; cuidador; COVID-19; cuidador formal; familia

\section{Resiliência do cuidador domiciliar da pessoa idosa durante a pandemia da COVID-19}

Resumo: Objetivo: o objetivo deste estudo é identificar o nível de resiliência de cuidadores domiciliares formais e informais de idosos maiores no lar em Ibagué, Colômbia, durante a pandemia ocasionada pela COVID-19. Métodos: estudo quantitativo, descritivo e transversal, com uma amostra de conveniência de 49 cuidadores domiciliares formais e informais de idosos. Aplicamos a Escala Breve de Enfrentamento Resiliente, um instrumento que consta de quatro artigos, para esses cuidadores. O questionário foi respondido por eles mesmos e, em alguns casos, por telefone. Os dados foram coletados em abril de 2020. Resultados: 35 mulheres e 14 homens participaram deste estudo. Cuidadores formais $(69,4 \%)$ e cuidadores informais, em sua maioria familiares (30,6 \%), tinham entre 18 e 30 anos (65,30 \%). Seus níveis de resiliência foram altos (16,3\%), moderados (61,3\%) e baixos $(22,4 \%)$. Houve uma associação significativa entre o tipo de cuidador e o nível de resiliência $(p \leq 0,05)$. Outras covariáveis estudadas não apresentaram uma associação significativa. Conclusões: devido às situações de estresse causadas pelo atendimento durante o isolamento social e ao risco de morte de idosos por causa da COVID-19, devem ser consideradas estratégias para melhorar a resiliência com relação às intervenções emocionais, cognitivas e socioculturais no cuidador.

Palavras-chave: resiliência; pessoa idosa; cuidador; COVID-19; cuidador formal; família 


\section{Introduction}

Formal and informal caregivers of the elderly with different dependency levels exhibit some degree of overload. Currently, when the COVID-19 pandemic threatens many human lives, especially the elderly who, in many cases, require permanent care according to their underlying disease, makes the caregivers' environment and feelings turn into fear and uncertainty. They must also face several challenges related to communication, compassion, and less-than-ideal care environments because of this pandemic (1).

Evidence suggests that two population groups are at an increased risk for severe COVID-19: people over 60 and people with chronic health conditions (chronic heart disease, diabetes, chronic respiratory disease, or cancer) (2). Colombia's coronavirus fatality rate rises daily: $26.62 \%$ in 60-69-year-olds, $27.64 \%$ in 70-79-year-olds, $13.31 \%$ in $80-89$-year-olds, and $5.46 \%$ among those over 90 years old. In Colombia, $73.03 \%$ of the deceased are over 60 years of age (3). In Spain, the number of deceased older adults until April 7 was 5,263 (17.5\%) in hospitals and 4,343 (82.5\%) in their homes. According to the same report, $13 \%$ of older people institutionalized in geriatric and protection centers have died in that country (2).

In China, formal caregivers of older adults with dementia in nursing homes experienced double stress related to fear of infection and concerns about residents' condition. Their anxiety level also increased; they developed signs of exhaustion after one month of total isolation (4).

The caregiver's role varies according to the care receiver's illness. The evidence shows that caregivers of people with dementia have a high burden of care, especially women. Although women reported more time providing care than men, the women's increased burden levels may also be explained by sociocultural differences in women's demands to assume primary care responsibilities. Male caregivers may be less attentive to their emotions, failing to recognize or report distress, or women may apply less effective coping strategies to relieve distress (5). The risk factors experienced by dementia caregivers included stress, challenging and demanding caregiving, frustration, lack of social support, and negative feelings (mainly sadness and anger). These data suggest that some stages during care can ultimately result in negative emotions (6). Caregivers' needs include:

a) implementing tailored interventions to address their demands and those of the patient;

b) incorporating caregiver input into care plans given the impact of caregiving on their lives;

c) following up on and reviewing the care plan regularly to support proactive versus reactive care;

d) considering the implementation of self-managed neighborhood teams involving weekly team meetings and technology to support coordination and overcome continuity problems in care providers and team communication challenges;

e) providing coordination, follow up, and financial support for respite care;

f) providing system navigation and an easily retrievable hard copy list of relevant health and community services to support patients and their caregivers, and

g) offering more patient support to reduce caregiver burden (7).

The caregiver claims to be able to rely on their experience and requires increasing individual strengths because, in many cases, they are family caregivers. Nhongho defines the caregiver's capacity as the "potential of the adult person who assumes the role of primary caregiver of a family member or an important person in a situation of disability" (8). When speaking of family or informal caregivers, reference is made to adult relatives or close friends who assume the responsibilities of caring for a loved one who lives with a chronic disabling disease and participate with him/her in decision-making. They carry out or supervise daily life activities seeking to compensate for the care receiver's existing dysfunctions (9).

It is essential to understand the resilience that formal and informal caregivers of older people are demonstrating now in their homes. Resilience is understood as a person's ability to recover from 
adverse situations, stress, threat, or mourning using tools at the individual and social levels, emerging restored from this situation and contributing positively to their sociocultural context (10). Resilience is also defined as "a dynamic process that results in positive adaptation in contexts of great adversity" (11). This concept is not only attributed to individual models of coping with adversity but can be contextualized within families and communities (12). This definition distinguishes three essential components that must be present in the concept of resilience: a notion of adversity or threat to human development, the positive adaptation to adversity, and the process that considers the dynamics between emotional, cognitive, and sociocultural mechanisms.

Protective factors for resilience are recognized as influences that modify, improve, or alter a person's response to some hazard that predisposes him/her to a non-adaptive outcome. Among the conditions that promote resilience are social support, the assessment of stressors, the style of coping used during care (13), and emotional intelligence. The latter is understood as the people's ability to recognize, understand, and regulate their own emotions and those of others, discriminate between them, and use the information to guide thoughts and actions (14-15). Resilience internal factors reported in the literature are having a positive attitude, spirituality, and religiosity. The external factors include the theoretical premise that resilience is an ecological process expressed and affected by multilevel attachments involving families, schools, and communities (16).

Resilience is a multifaceted response to the caregiver's role and is influenced by many interrelated factors (17). It is associated with developing skills such as control over memories of a traumatic situation, integrating memory and emotion, regulating trauma-related emotions, controlling symptoms, self-esteem, internal cohesion, establishing safety signs, understanding the impact of trauma, and achieving a positive meaning (18). Likewise, resilience positively affects physical health, improves survival and mental health, and significantly reduces the risk of developing depression, anxiety, and stress (19).
Resilience research has shown that as people age and develop, they tend to learn to deal more effectively with negative emotions in stressful situations. It has also been shown that more resistant people tend to extract positive coping strategies from difficult situations (20).

The study of resilience in formal and informal inhome caregivers of older people arises from observing their situation of confinement and social isolation and what the process of assisting a care-dependent person implies. This role poses difficulties in daily activities, with negative psychological aspects when dealing with life-threatening conditions.

\section{Methods}

This descriptive cross-sectional study has a quantitative approach. It has a sample of 49 formal and informal in-home caregivers of older people in Ibagué; they were selected for convenience and decided to participate after understanding the study's nature and objectives. Initially, the researchers interviewed the participants face-to-face and, in some cases, by telephone call, after following the research protocol and signing the informed consent. The following instruments were used to collect the information:

- A sociodemographic information protocol designed for this study to collect data about gender, age, time as a caregiver, comorbidity of the care receiver, and caregiver type

- The Brief Resilient Coping Scale (BRCs) by Sinclair and Wallston (21-22), which assesses individuals' ability to cope with stress adaptively. It has a one-dimensional measure made up of four items. The original version presented a Cronbach's alpha coefficient (as an internal consistency measure) of .69 , a test-retest correlation coefficient of .71, and good adjusted goodness of fit index $(\chi 2=2.13, p=.03$, CFI $=.99$, SRMR $=.02$, and RMSEA $=.01)$. The items were scored on a Likert-type scale from 1 (does not describe me at all) to 5 (describes me very well). Final scores ranged between 4 and 20. For this study, we used Limonero's translation (23). 
- The Barthel index as a measurement instrument for the person's ability to carry out ten basic daily life activities, obtaining a quantitative estimate of the dependency level. The activities are rated differently, assigning $0,5,10$, or 15 points. The global range can vary between 0 (total dependence) and 100 points (independence) (24).

We carried out the analysis of the information through the BRCs variables. The qualitative variables were presented as the distribution of absolute and relative frequencies, and the quantitative ones as measures of central tendency, $S D$, and variation. The groups' normality was tested with the Kolmogorov-Smirnov test. We performed the Student's t-test when both groups presented data with normal distribution and the Mann-Whitney or Kruskal-Wallis test when asymmetric. For all analyses, we considered a significance level of $\leq .05$. The information was processed through sPss (Statistical Package for the Social Sciences) 22.0. The study was carried out in April 2020 and approved by the ethics committee and Resolution 8430/1993, which regulates research in Colombia (25).

\section{Results}

Firstly, we studied sociodemographic variables. There were 35 female $(71.4 \%)$ and 14 male $(28.6 \%)$ caregivers of working age; $69.4 \%$ were formal caregivers (healthcare professionals) and 30.6\% informal caregivers (family). This distribution corresponds to a visible phenomenon in the Colombian context that explains reduced birth rates, smaller households, and family verticalization that have decreased the number of formal caregivers in some socioeconomic levels (26).

Among older adults' comorbidities, non-transmissible chronic diseases are in the first place, followed by neurological diseases. The Barthel index showed $30.6 \%$ of older adults with severe dependence. Regarding time as a caregiver, we found that $30.6 \%$ have performed this task for 1 to 2 years. We tried to establish a relationship between the caregiver's sociodemographic characteristics, the degree of dependency of the older adult receiving care, and the caregiver's resilience level, finding no statistical significance (see Table 1).

Table 1. Sample characteristics

\begin{tabular}{|c|c|c|}
\hline Item & Frequency & Percentage \\
\hline \multicolumn{3}{|c|}{ Gender } \\
\hline Female & 35 & 71.4 \\
\hline Male & 14 & 28.6 \\
\hline \multicolumn{3}{|c|}{ Age } \\
\hline $18-30$ years old & 32 & 65.30 \\
\hline 31-43 years old & 9 & 18.4 \\
\hline $44-56$ years old & 5 & 10.2 \\
\hline $57-68$ years old & 2 & 4.1 \\
\hline More than 68 years old & 1 & 2 \\
\hline \multicolumn{3}{|c|}{ Care receiver diseases } \\
\hline High blood pressure & 8 & 16.3 \\
\hline Diabetes mellitus & 5 & 10.2 \\
\hline Cancer & 7 & 14.3 \\
\hline Alzheimer's disease & 2 & 4.1 \\
\hline Arthritis & 3 & 6.1 \\
\hline Parkinson's disease & 3 & 6.1 \\
\hline Kidney failure & 4 & 8.2 \\
\hline Stroke sequels & 4 & 6.8 \\
\hline Intellectual disability & 2 & 4.1 \\
\hline Neurological diseases & 6 & 12.2 \\
\hline Osteomuscular diseases & 5 & 10.2 \\
\hline
\end{tabular}

\section{Barthel index dependence level}

\begin{tabular}{lcc}
\hline Total dependence & 7 & 14.3 \\
\hline Severe dependence & 15 & 30.6 \\
\hline Moderate dependence & 9 & 18.4 \\
\hline Slight dependence & 12 & 24.5 \\
\hline Independence & Time as a caregiver & 12.2 \\
\hline & 15 & \\
\hline 1-2 years & 11 & 22.6 \\
\hline 3-4 years & 10 & 20.4 \\
\hline 5-6 years & 13 & 26.5 \\
\hline More than 7 years & &
\end{tabular}




\begin{tabular}{lcc}
\hline \multicolumn{3}{c}{ Caregiver's relationship with the care receiver } \\
\hline Mother & 4 & 8.2 \\
\hline Son & 9 & 18.4 \\
\hline Wife & 1 & 2 \\
\hline Another relative & 1 & 2 \\
\hline Caregiver & 34 & 69.4 \\
\hline
\end{tabular}

Source: Own elaboration.

Regarding the BRCs, the mean was 14.39 and the variance 6.95, with a Cronbach's alpha of 69 for four items. The caregiver resilience level indicates that it is moderate in $61.2 \%$ of the participants. However, it should be considered that caregivers are mostly formal; therefore, they do not have a family relationship with the older adult they take care of. Table 2 lists the results of the different resilience levels.

Table 2. Caregiver resilience levels

\begin{tabular}{lccc} 
Resilience level & Frequency & Percentage \\
\hline Low resilience & 11 & 22.4 \\
\hline Moderate resilience & 30 & 61.2 \\
\hline High resilience & 8 & 16.3 \\
\hline Total & 49 & 100 \\
\hline
\end{tabular}

Source: Own elaboration.

An attempt was made to identify a relationship between gender and resilience levels, finding that $70 \%$ of women have a moderate resilience level, while in men, it reaches $30 \%$. These data coincide with studies aimed at evaluating resilience by gender. It is striking that the study by González, Arratia, and Valdés (27) found that women require external support to be resilient (Table 3).

Table 3. Caregiver resilience levels and gender

\begin{tabular}{l|c|c|c|c} 
Gender & \multicolumn{1}{l}{$\begin{array}{l}\text { Low } \\
\text { resilience }\end{array}$} & $\begin{array}{l}\text { Moderate } \\
\text { resilience }\end{array}$ & $\begin{array}{l}\text { High } \\
\text { resilience }\end{array}$ & Total \\
\cline { 2 - 5 } Female & 7 & 21 & 7 & 35 \\
\cline { 2 - 5 } & $63.60 \%$ & $70.00 \%$ & $87.50 \%$ & $71.40 \%$ \\
\hline \multirow{2}{*}{ Male } & 4 & 9 & 1 & 14 \\
\cline { 2 - 5 } & $36.40 \%$ & $30.00 \%$ & $12.50 \%$ & $28.60 \%$ \\
\hline
\end{tabular}

Source: Own elaboration.
The relationship between caregiver type (formal and informal) and the caregiver resilience level had a significance level of $p<.05$. In other words, a relationship is established between caregiver type and resilience level, considering that, in this study, $69.4 \%$ were formal caregivers (professional) of working age that have been serving as such for 1-2 years (Table 4).

Table 4. Correlation between resilience level, gender, and caregiver relationship

\begin{tabular}{|c|c|c|c|c|}
\hline & & $\begin{array}{l}\text { Resilience } \\
\text { level }\end{array}$ & Gender & $\begin{array}{l}\text { Caregiver } \\
\text { type }\end{array}$ \\
\hline \multirow{2}{*}{$\begin{array}{l}\text { Resilience } \\
\text { level }\end{array}$} & R. & 1 & -.156 & -.241 \\
\hline & $\begin{array}{l}\text { Sig. } \\
\text { (bilateral) }\end{array}$ & & -.156 & ${ }^{*} .055$ \\
\hline \multirow[b]{2}{*}{ Gender } & R. & -.156 & 1 & .188 \\
\hline & $\begin{array}{l}\text { Sig. } \\
\text { (bilateral) }\end{array}$ & .284 & & .196 \\
\hline \multirow{2}{*}{$\begin{array}{l}\text { Caregiver } \\
\text { type }\end{array}$} & R. & -.241 & .188 & 1 \\
\hline & $\begin{array}{l}\text { Sig. } \\
\text { (bilateral) }\end{array}$ & *.055 & .196 & \\
\hline
\end{tabular}

Note. *Statistical significance $p<.05$ (bilateral) Source: Own elaboration.

\section{Discussion}

The present study finds a significant association between caregiver type (formal and informal) and resilience levels. Formal or professional caregivers exhibited a moderate resilience level. These results are like other studies that found that the act of caring, even if assumed by a professional caregiver, involves an emotional burden when empathizing with the cared person. Such studies highlight the relevance of approaching care from the ethical principles of respect for autonomy, beneficence, and non-maleficence (28).

New bioethical and philosophical approaches to the elderly's crucial social value in different societies are proposed from research and reflection. In the best scenario, these approaches will help recognize their intrinsic value as human beings to grant them their owed respect and a context that does not make them fear the future (29).

These combined elements reflect the need for formal caregivers, duly trained and empowered, 
who achieve higher resilience levels (30). On the other hand, being a professional caregiver helps face tense situations differently, compared to informal caregivers (especially family members) who show many risk factors such as increased caregiver burden and low resilience (31).

A severe dependence level due to the care receiver's pathologies, the heavy physical, psychological, and emotional demands of the act of caring, and any changes in the caregiver's dimensions cause anguish. However, this condition significantly reduces when promoting resilience (32-34). Literature focuses on informal or family caregivers' resilience, especially when taking care of people with dementia (35) and Alzheimer's disease (36-37), and their high depression, anxiety, hopelessness, emotional burden, stress, and anguish levels.

Adopting the role of caregiver and being able to accept the situation in everyday life has been described from qualitative research by family caregivers, based on broad categories ranging from "the onset of symptoms" to "the need for the person not to lose their essence" and "restoring hope" (38). These remarks show the importance of the time elapsed from the moment the caregiver role is assumed for the mental development of passive coping strategies focused on the problem, such as problem avoidance, wishful thinking (39), and higher resilience levels (40).

In addition to the documented factors, the family caregiver's typical profile is a woman over 57 years of age, stay-at-home spouse, relative in the first degree of consanguinity, economically dependent, and with a low education level (41-42). The caregiver's age is a variable of great interest in this study because most of them were adults of working age and professional caregivers who received compensation for this activity; this group showed a moderate resilience level. Besides, research that has characterized resilience at different stages of the life cycle, supported by psychology, reports that adults are the most resilient group regarding their emotional regulation and problem-solving skills (27), added to self-esteem and emotional intelligence, which have been well-documented as modulating factors of resilience (43). These factors could directly impact how caregivers face challenging situations that require early identification and treatment of patients' emotional and physical needs (44).

The caregivers' context during the COVID-19 pandemic has changed, adding another stressor to their daily activities. Altogether, human talent specialized in geriatric care should be present in all settings, starting with primary care units (which have not been given enough attention, while high budgets are allocated mainly to hospitals and clinics). Even though the significance of hospital care services is recognized, efforts to promote health, especially for older adults and their caregivers, are no less important (45).

Nurses have made vital contributions to knowledge construction with their medium-range theories to address care in life-threatening situations such as the one currently faced. These theories identify resilience threatening factors, either in the caregiver or in the elderly, to obtain better responses from each person facing adversity and, thus, strengthen their capacities, guaranteeing better results in daily interventions (46-47). This pandemic has highlighted the priority of giving primary care the possibility of strengthening external resilience protective factors with well-designed social support programs (48-49).

The main limitation of the study is the use of non-probabilistic sampling. However, this study focuses on the professional caregiver resilience who, despite being paid, may be at risk of developing occupational burnout during this pandemic and in other stressful situations (50).

\section{Conclusions}

Resilience is a dynamic process over time and results from the combination and interaction between internal and external factors, such as the family, social, and cultural environments, which facilitate overcoming risk and adversity constructively and promote new resilience factors in previous stages.

It is crucial to learn from the experiences after the outbreaks of this disease, older adult care during the COVID-19 pandemic (as it has tested the caregiver's resilience level and coping strategies), and the health systems' ability to establish 
more effective care procedures, from health promotion, focused on caring for the caregiver when an additional stressor becomes part of their daily life.

Caregivers of older people are generally subjected to chronic stress, even more so in pandemic times due to the social isolation and risk of death of older adults caused by COVID-19. This situation has considerable repercussions on physical and emotional health, which in most cases affect caregivers' resilience level, hence the need to design and implement specific interventions to strengthen the spiritual, emotional, cognitive, and sociocultural dimensions.

The literature repeatedly shows that informal caregivers are mostly women, stay-at-home moms, daughters, or wives of the person receiving care. Due to reduced birth rates, smaller households, and family verticalization, the number of formal caregivers in some social levels has decreased, clearly showing the feminization of care for older adults.

Formal caregivers must face multiple stressors at both work and personal levels, giving them a high emotional burden affecting their adjustment to the work environment, just like informal caregivers. However, the specific role of caring as an occupation (receiving a salary and meeting a schedule), added to the current pandemic situation, makes the work differ considerably from the one carried out by informal caregivers. This situation can affect caring for the elderly and the resilience level, which requires more robust support systems in this new scenario. Women's resilience level is significantly higher; however, they require external support from a strong family network to become resilient.

Caregivers' resilience levels are not directly related to age ranges. There is only a significant difference between caregivers aged 19-24 years who report high resilience scores and adults aged 46-55 years who reported low levels. The study results contribute to clinical trials that explore strategies to strengthen caregivers' resilience.

The COVID-19 pandemic made visible the need to strengthen caregivers' external resilience protective factors by designing and implementing relevant social support programs according to the country or world conditions.

Research during this pandemic must contemplate different variables that caregivers have and know the role that resilience plays at present, in which lifestyle and family dynamics are no longer the same. Adults are the most resilient group regarding emotional regulation and problem-solving skills. These skills are critical in events older adults must face, such as losing loved ones, the appearance of illnesses, disabilities, loss of autonomy, retirement, and financial losses. Such situations could make people design new life guidelines and strategies to overcome crises. Self-esteem, emotional intelligence (documented as resilience modulating factors), and how this contingency could be managed are crucial factors in maintaining a good emotional condition and can directly impact how caregivers face challenging situations that require early identification and treatment of the elderly's emotional and physical needs.

\section{Acknowledgments}

The researchers express gratitude to the participants in this study.

\section{Conflict of interest}

This manuscript was prepared and reviewed with all the authors' participation, who declare no conflict of interest.

\section{Financing}

This study has not been externally financed.

\section{References}

1. Sonis J, Kennedy M, Aaronson E, Baugh J, Raja A, Yun B, et al. Humanism in the Age of COVID-19: Renewing Focus on Communication and Compassion. West J Emerg Med [Internet]. 2020;21(3):0-4. DoI: 10.5811/westjem.2020.4.47596

2. Public Health England. COVID-19: guidance on residential care provision; 2020. Available from: https:// 
www.paho.org/es/decada-envejecimiento-saludable-2020-2030

3. Instituto Nacional de Salud. COVID-19 Colombia; 2020 April 30. Available from: https://www.ins.gov. co/Noticias/Paginas/Coronaviru.

4. Wang H, Li T, Barbarino P, Gauthier S, Brodaty $\mathrm{H}$, Molinuevo JL, et al. Dementia care during COVID-19. Lancet [Internet]. 2020;395(10231):11901. DOI: $10.1016 / \mathrm{S} 0140-6736(20) 30755-8$

5. Ruisoto P, Contador I, Fernández-Calvo B, Serra L, Jenaro C, Flores N, et al. Mediating effect of social support on the relationship between resilience and burden in caregivers of people with dementia. Arch Gerontol Geriatr [Internet]. 2020;86(June 2019):103952. DOI: 10.1016/j.archger.2019.10 3952

6. Bekhet AK, Avery JS. Resilience from the Perspectives of Caregivers of Persons with Dementia. Arch Psychiatr Nurs [Internet]. 2018;32(1):19-23. DoI: 10.1016/j.apnu.2017.09.008

7. Valaitis RK, Markle-Reid M, Ploeg J, Butt ML, Ganann $\mathrm{R}$, Murray $\mathrm{N}$, et al. An evaluation study of caregiver perceptions of the Ontario's Health Links program. PLoS One [Internet]. 2020;15(2):1-22. DOI: 10.1371/journal.pone.0229579

8. Nkongho N. Caring ability inventory. In: Watson J, editor. Assessing and measuring caring in nursing and health sciences. New York: Springer; 2009. p. 117-24.

9. Barrera L, Galvis C, Moreno ME, Pinto N, Pinzon ML, Romero E, et al. La habilidad de cuidado de los cuidadores familiares de personas con enfermedad crónica. Invest educ enferm. 2006;24(1):36-46.

10. Luthar SS, Cicchetti D, Becker B. The Construct of Resilience: A critical evaluation and guidelines for future work. Child Dev [Internet]. 2000 May;71(3):54362. DOI: $10.1111 / 1467-8624.00164$

11. Garcia Vesga MC, Domiguez De la Ossa E. Theoretical development of resilience and its application in adverse situations: An analytical review. Rev Latinoam Cienc Soc Niñez Juv [Internet]. 2013;11(1):63-77. Available from: http://www.scielo.org.co/scielo.php? pid=S1692-715X2013000100003\&script=sci_arttext\&tlng=pt

12. Jiménez-Picón N, Velasco-Sánchez MA, Romero-Martín M. To family resilience as an asset in helath. An Sist Sanit Navar [Internet]. 2019;42(1):121-4. Available from: https://recyt.fecyt.es/index.php/ ASSN/article/view/70266/43592

13. Martínez Rodríguez L, Fernández Castillo E, González Martínez E, de la C. Ávila Hernández Y,
Lorenzo Carreiro A, Vázquez Morales HL. Social support and resilience: protective factors in primary caregivers of hemodialysis patients. Enferm nefrol [Internet]. 2019;22(2):130-9. Available from: http://scielo.isciii.es/scielo.php?script=sci_arttext\&pid=S2254-28842019000200130\&lng=es\&n$\mathrm{rm}=\mathrm{iso} \& \mathrm{t} \operatorname{lng}=\mathrm{es}$

14. Limonero JT, Tomás-Sábado J, Fernández-Castro J, Gómez-Romero MJ, Ardilla-Herrero A. Estrategias de afrontamiento resilientes y regulación emocional: Predictores de satisfacción con la vida. Behav Psychol Psicol Conduct [Internet]. 2012;20(1):183-96. Available from: https://www.researchgate.net/profile/ Joaquin_Limonero2/publication/234139556_Resilient_coping_strategies_and_emotion_regulation_predictors_of_life_satisfaction_Estrategias_ de_afrontamiento_resilientes_y_regulacion_emocional_predictores_de_satisfaccion_con_la_vida/ links/0912f50f875b5c8ae5000000.pdf

15. Liu Y, Wang Z, Lü W. Resilience and affect balance as mediators between trait emotional intelligence and life satisfaction. Pers Individ Dif [Internet]. 2013;54(7):850-5. DoI: 10.1016/j.paid.2012.12.010

16. Greene RR, Galambos C, Lee Y. Resilience Theory: Theoretical and Professional Conceptualizations. J Hum Behav Soc Environ. 2004;8(4):75-91. DOI: 10.1300/J137v08n04_05

17. Teahan Á, Lafferty A, McAuliffe E, Phelan A, O’Sullivan $\mathrm{L}$, O'Shea $\mathrm{D}$, et al. Resilience in family caregiving for people with dementia: A systematic review. Int J Geriatr Psychiatry [Internet]. 2018;33(12):158295. DOI: 10.1002/gps.4972

18. Goldzweig G, Merims S, Ganon R, Peretz T, Altman A, Baider L. Informal caregiving to older cancer patients: Preliminary research outcomes and implications. Ann Oncol [Internet]. 2013;24(10):2635-40. DOI: $10.1093 /$ annonc/mdt 250

19. Córdoba AMC, Poches DKP. Resiliencia y variables asociadas en cuidadores informales de pacientes con Alzheimer. Rev Colomb Psicol [Internet]. 2016;25(1):33-46. DoI: 10.15446/rcp.v25n1.44558

20. Shahzad B, Collard J. The Role of Functional and Dysfunctional Negative Emotions, Resilience and Mindfulness in Well-Being. Psychol Behav Sci Int J [Internet]. 2019;13(2):001-0012. DOI: 10.19080/PBSIJ.2019.10.555857.

21. Sinclair VG, Wallston KA. The development and psychometric evaluation of the Brief Resilient Coping Scale [Internet]. Assessment. 2004;11(1):94-101. DOI: $10.1177 / 1073191103258144$ 
22. Caycho-Rodríguez T, Ventura-León J, García-Cadena $\mathrm{CH}$, Tomás JM, Domínguez-Vergara J, Daniel L, et al. Evidencias Psicométricas de una Medida Breve de Resiliencia en Adultos Mayores Peruanos no Institucionalizados. Psychosoc Interv [Internet]. 2018;27(2):073-9. DOI: 10.5093/pi2018a6

23. Limonero JT, Tomás-Sábado J, Gómez-Romero MJ, Maté-Méndez J, Sinclair VG, Wallston KA, et al. Evidence for validity of the brief resilient coping scale in a young spanish sample. Span J Psychol [Internet]. 2014;17(2):1-9. DOI: 10.1017/sjp.2014.35

24. Cid-Ruzafa J, Damián-Moreno J. Valoracion de la discapacidad fisica: El Indice de Barthel. Rev Esp Salud Publica [Internet]. 1997;71(2):127-37. DoI: 10.1590/s1135-57271997000200004

25. Resolucion_008430_1993 [Internet]. Available from: http://www.urosario.edu.co/EMCS/Documentos/investigacion/resolucion_008430_1993/

26. Cerquera Córdoba AM, Galvis Aparicio MJ. Efectos de cuidar personas con Alzheimer: un estudio sobre cuidadores formales e informales. Pensam Psicológico [Internet]. 2014;12(1):149-67. DoI: 10.11144/javerianacali.ppsi12-1.ecpa

27. González-Arratia López Fuentes NI, Valdez Medina JL. Resiliencia. Diferencias por Edad en Hombres y Mujeres Mexicanos. Acta Investig Psicológica [Internet]. 2015;5(2):1996-2010. DOI: 10.1016/S20074719(15)30019-3

28. Ferreira da Silva C, Silva JV da, Ribeiro MDP. Cuidadores formales y asistencia paliativa desde la mirada de la bioética. Rev Bioet. 2019;27(3):535-41. DOI: $10.1590 / 1983-80422019273338$.

29. Velázquez L. Un enfoque filosófico de la vejez y algunas consideraciones bioéticas. Bioeth Updat [Internet]. 2020;6(1):46-61. DoI: 10.1016/j.bioet.2020.03.001

30. Navarro-Abal Y, López-López MJ, Climent-Rodríguez JA, Gómez-Salgado J. Sobrecarga, empatía y resiliencia en cuidadores de personas dependientes. Gac Sanit [Internet]. 2019;33(3):268-71. DoI: 10.1016/j.gaceta.2017.11.009

31. Vaingankar JA, Chong SA, Abdin E, Picco L, Jeyagurunathan A, Zhang YJ, et al. Care participation and burden among informal caregivers of older adults with care needs and associations with dementia. Int Psychogeriatrics [Internet]. 2016;28(2):221-31. DOI: $10.1017 /$ s104161021500160x

32. Ertl MM, Trapp SK, González Arredondo S, Rodríguez Agudelo Y, Arango-Lasprilla JC. Perceived stress, resilience, and health-related quality of life among Parkinson's disease caregivers in Mexico. Heal
Soc Care Community [Internet]. 2019;27(5):1303-10. DoI: $10.1111 /$ hsc. 12767

33. Palacio GC, Krikorian A, Gómez-Romero MJ, Limonero JT. Resilience in Caregivers: A Systematic Review. Am J Hosp Palliat Med [Internet]. 2019;37(8):648-658. DOI: 10.1177/1049909119893977

34. Goudarzi F, Abedi H, Zarea K, Ahmadi F, Hosseinigolafshani SZ. The Resilient Care of Patients with Vegetative State at Home: a Grounded Theory. J Caring Sci [Internet]. 2018;7(3):163-75. DOI: 10.15171/ jcs. 2018.026

35. Petriwskyj A, Parker D, O’Dwyer S, Moyle W, Nucifora N. Interventions to build resilience in family caregivers of people living with dementia: a comprehensive systematic review. JBI database Syst Rev Implement reports [Internet]. 2016;14(6):238-73. DOI: 10.11124/jbisrir-2016-002555

36. Wilks SE, Little KG, Gough HR, Spurlock WJ. Alzheimer's aggression: Influences on caregiver coping and resilience [Internet]. J Gerontol Soc Work. 2011;54(3):260-75. DOI: 10.1080/01634372.2010.544531

37. Ho L, Bloom PA, Vega JG, Yemul S, Zhao W, Ward $\mathrm{L}$, et al. Biomarkers of Resilience in Stress Reduction for Caregivers of Alzheimer's Patients. NeuroMolecular Med [Internet]. 2016;18(2):177-89. DoI: 10.1007/ s12017-016-8388-8

38. Rubio Acuña M, Doren FM, Campos Romero S, Rojas CA. Adaptando mi vida: vivencias de cuidadores familiares de personas con enfermedad de Alzheimer. GEROKOMOS [Internet]. 2018;29(2):54-8. Available from: http://scielo.isciii.es/scielo.php?pid=S1134-928 X2018000200054\&script=sci_arttext\&tlng=pt

39. Rodríguez Esteban A, Pérez Álvarez L. Estrategias de afrontamiento en cuidadoras de personas con alzhéimer. Influencia de variables personales y situacionales. Rev Española Discapac [Internet]. 2019;7(1):153-71. DOI: 10.5569/2340-5104.07.01.08

40. Chavez J, Franco B, Gabriela L, Ocampo E, Rangel $\mathrm{S}$, Tovar I, et al. Capacidad de autocuidado y estrategias de afrontamiento en la persona con enfermedad cronica. Verano la Cienc [Internet]. 2019;5(1). Available from: http://148.214.90.90/index.php/jovenesenlaciencia/article/view/3191/2673

41. Bello M, Leon G, Covena MI. Factores que predominan sobrecarga en el cuidador formal e informal geriatrico con deficit de autocuidado. Univ y Soc [Internet]. 2019;11(5):382-95. Available from: http://scielo.sld.cu/scielo.php?script=sci_arttext\&pid=S2218-36202019000500385

42. Brigola A, Luchesi M, Rossetti S. Perfil de saúde de cuidadores familiares de idosos e sua relação com 
variáveis do cuidado: um estudo no contexto rural. Rev Bras Geriatre Gerontol [Internet]. 2017;20(3):410 22. DoI: $10.1590 / 1981-22562017020.160202$

43. González Guerra A, Fonseca Fernández M, Valladares González AM, Magda L, Angulo L. Factores moduladores de resiliencia y sobrecarga en cuidadores principales de pacientes oncológicos avanzados. Univ Ciencias Medicas [Internet]. 2017;7(1):26-32. Available from: http://scielo.sld.cu/ pdf/rf/v7n1/rf05107.pdf

44. Henz U. Informal caregiving at working age: Effects of job characteristics and family configuration. J Marriage Fam [Internet]. 2006;68(2):411-29. DoI: 10.1111/j.1741-3737.2006.00261.x

45. Tarazona-Santabalbina FJ, Martínez-Velilla N, Vidán MT, García-Navarro JA. COVID-19, adulto mayor y edadismo: errores que nunca han de volver a ocurrir. Rev Esp Geriatr Gerontol [Internet]. 2020;7-8. DOI: 10.1016/j.regg.2020.04.001
46. Arriagada F, Jara P. Resiliencia como estrategia para la práctica de enfermería. Una propuesta teórica. Beness - Rev Enfermería [Internet]. 2016;1(1):58-67. Available from: http://benessere.uv.cl/images/revista/revista_n1/6_resiliencia.pdf

47. Carrillo GM, Gómez Ramírez OJ, Arias EM. Teorías de enfermería para la investigación y práctica en cuidado paliativo. Rev Latinoam Bioética [Internet]. 2016;17(1):60-79. DoI: 10.18359/rlbi.1764

48. Ramón Martínez Riera J, Gras-Nieto E. Atención Domiciliaria Y COVID-19. Antes, Durante Y Después Del Estado De Alarma. Enfermería Clínica [Internet]. 2020. DoI: 10.1016/j.enfcli.2020.05.003

49. Oñate L, Calvete E. Una aproximación cualitativa a los factores de resiliencia en familiares de personas con discapacidad intelectual en España. Psychosoc Interv [Internet]. 2017;26(2):93-101. DOI: 10.1016/j. psi.2016.11.002

50. Macaya BP, Aranda GF. Cuidado y autocuidado en el personal de salud: enfrentando la pandemia COVID-19. RevChilAnest [Internet]. 2020;49(3):35662. DoI: $10.25237 /$ revchilanestv49n03.014 
